\title{
Dobre praktyki edukacji wielokulturowej na przykładzie Społecznego Gimnazjum nr 20 „Raszyńska” w Warszawie
}

\section{KEYWORDS}

education of foreigners in the Polish education system, multicultural education, intercultural education, Social Secondary School No. 20 "Raszyńska” in Warsaw
Figiel Angelika, Dobre praktyki edukacji wielokulturowej na przykładzie Społecznego Gimnazjum nr 20 "Raszyńska" w Warszawie [Good practices in multicultural education based on the example of the "Raszyńska" Community Junior Secondary School No. 20 in Warsaw]. Kultura - Społeczeństwo - Edukacja nr 1(13) 2018, Poznań 2018, pp. 127-142, Adam Mickiewicz University Press. ISSN 2300-0422. DOI 10.14746/kse.2018.13.10.

This article is an attempt to present the good practices of intercultural education. By the introducing into the main problems, the author presents the education rules of foreigners in the Polish education system, indicating the most important aspects of Polish law regulations. Then defines the one of the most important concepts of intercultural education and multicultural education, discussing its main goals and tasks. The crucial question raised in the text is the role of the school in the intercultural education and shaping of intercultural competence in education among pupils by the teacher. At this point, the author attempts to answer the question whether and how Polish schools and teachers are prepared to accept foreign children? And what is the role of the teacher in intercultural education? In the second part of the text, they presented good practices of intercultural education as an example the Social Secondary School No. 20 "Raszyńska" in Warsaw.

\section{Wprowadzenie}

W ostatnich latach obserwuje się rosnącą skalę migracji, wraz z którą w szkołach pojawia się coraz więcej uczniów cudzoziemców nieznających języka polskiego lub znających go w stopniu niedostatecznym. Często są to osoby wychowane w kultu- 
rze, w której obowiązują inne zwyczaje niż te, które uznajemy w naszym kraju za normę. Polskie placówki edukacyjne na mocy prawa zobowiązane są do przyjęcia dzieci cudzoziemców. Ich włączanie w polski system oświaty staje się wyzwaniem dla wielu szkół i nauczycieli, przed którymi stoi nieproste zadanie. Z jednej strony muszą przygotować polskich uczniów na przyjęcie do zespołu klasowego ucznia cudzoziemca, z drugiej zaś dokonać wszelkich starań, by nowy uczeń mógł czuć się w szkole bezpiecznie i został zaakceptowany przez rówieśników.

Według prawa cudzoziemiec to osoba, która nie ma obywatelstwa polskiego (Dz.U. z 2003 r., nr 128, poz. 1175). Wśród wszystkich cudzoziemców wymienia się uchodźców i osoby starające się taki status uzyskać (Dz.U. z 2003 r., nr 128, poz. 1176) oraz obywateli Unii Europejskiej (Dz.U. z 2006 r., nr 144, poz. 1043). Dokumentami zapewniającymi uchodźcom ochronę zgodną z międzynarodowymi standardami jest konwencja genewska z 1951 roku oraz protokół nowojorski z 1967 roku, które zostały podpisane przez Polskę 2 września 1991 roku. Zgodnie z konwencją uchodźca to osoba, która

na skutek uzasadnionej obawy przed prześladowaniami z powodu swojej rasy, religii, narodowości, przynależności do określonej grupy społecznej lub z powodu przekonań politycznych przebywa poza granicami kraju, którego jest obywatelem, i nie może lub nie chce z powodu tych obaw korzystać z ochrony tego państwa, albo która nie ma żadnego obywatelstwa i znajdując się na skutek podobnych zdarzeń poza państwem swojego dawnego stałego zamieszkiwania, nie może lub nie chce z powodu tych obaw powrócić do tego państwa. (Dz.U. z 1991 r., nr 119, poz. 515)

Najnowsze dane z dnia 1 września 2015 roku udostępnione przez Urząd do Spraw Cudzoziemców wskazują, że w Polsce przebywa 945 dzieci w wieku objętym obowiązkiem szkolnym, tj. od 6 do 18 lat. Jest to liczba nieco wyższa niż w 2014 roku, kiedy w podanym przedziale wiekowym na dzień 1 września zarejestrowanych było 885 dzieci. Wśród uczniów dominują młodzi obywatele Ukrainy - jest ich 418. W dalszej kolejności znajdują się następujące narodowości: Rosja - 370 (w tym 321 Czeczenia), Kirgistan - 44, Gruzja - 40, Syria - 32 (www.udsc.gov.pl/ uchodzcy-w-polskiej-szkole/).

Zasady kształcenia cudzoziemców w polskim systemie oświaty regulują dwa dokumenty: Ustawa o systemie oświaty z 7 września 1991 r. (Dz.U. z 2004 r., nr 256, poz. 2572 ze zm.) oraz Rozporządzenia Ministra Edukacji Narodowej z dnia 30 lipca 2015 r. w sprawie warunków i trybu przyjmowania do publicznych przedszkoli, innych form wychowania przedszkolnego, szkół i placówek osób niebędących obywatelami polskimi oraz obywateli polskich, którzy pobierali naukę w szkołach funkcjonujących w systemach oświaty innych państw, a także organi- 
zacji dodatkowej nauki języka polskiego, dodatkowych zajęć wyrównawczych oraz nauki języka i kultury kraju pochodzenia (Dz.U. z 2015 r., poz. 1202). Ich najważniejsze zapisy zostaną omówione poniżej.

\section{Zasady kształcenia cudzoziemców w polskim systemie oświaty}

Zgodnie z art. 15.2. Ustawy o systemie oświaty każde dziecko w wieku 7 lat podlega obowiązkowi szkolnemu, który rozpoczyna się z początkiem roku szkolnego i trwa do ukończenia gimnazjum, jednakże nie dłużej niż do ukończenia 18. roku życia. Obowiązkowi szkolnemu podlega każde dziecko, które znajduje się na terytorium RP, niezależnie od statusu prawnego, w tym także cudzoziemcy - niezależnie od tego, czy znajdują się w Polsce legalnie, czy też nielegalnie (art. 94a.1.).

Za realizację obowiązku szkolnego odpowiedzialni są rodzice, ale kontrolę nad nimi w tym zakresie sprawuje dyrektor szkoły, w okręgu którego dziecko ma miejsce zamieszkania, albo organy gminy - w przypadku obowiązku nauki, realizowanego po ukończeniu gimnazjum (art. 14 ust. 3). Zgodnie $\mathrm{z}$ art. 14b do kluczowych obowiązków rodziców należy dopełnienie czynności związanych ze zgłoszeniem dziecka do szkoły bądź przedszkola, a także zapewnienie regularnego uczęszczania dziecka na zajęcia. W przypadku niedopełnienia tego obowiązku dyrektor zobligowany jest podjąć odpowiednie działania w celu jego egzekucji, o czym mowa w przepisach zawartych w art. 19 i 20 niniejszej ustawy.

Szczegóły dotyczące przyjmowania dzieci cudzoziemców do szkół publicznych określa Rozporządzenie Ministra Edukacji Narodowej z dnia 1 kwietnia 2010 roku. Przewiduje ono, że dzieci te są przyjmowane do wszystkich placówek na zasadach obowiązujących obywateli polskich ( $\$ 2$ ust. 1 rozporządzenia). Zgodnie $z \$ 2$ ust. 2 rozporządzenia następuje ono na podstawie świadectw lub innych dokumentów potwierdzających ukończenie za granicą pewnego etapu edukacji albo też potwierdzenia, którą klasę dziecko ukończyło i jaka jest suma lat jego nauki szkolnej. Wyjątkiem w tym zakresie jest brak dokumentów potwierdzających ukończenie przez dziecko odpowiedniej szkoły lub klasy za granicą. W tym przypadku przed przyjęciem dziecka do szkoły dyrektor przeprowadza rozmowę kwalifikacyjną, której wynik powinien zadecydować o tym, do jakiej klasy dziecko powinno zostać przyjęte, o czym mówi $\$ 2$ ust. 4 i 5 .

Polskie regulacje prawne określają także dodatkową pomoc dla dzieci cudzoziemskich. Uczniowie ci mają prawo do korzystania z bezpłatnej nauki języka polskiego oraz zajęć wyrównawczych. Art. 94a ust. 4 ustawy określa, że w przypadku 
braku znajomości przez dziecko cudzoziemskie języka polskiego lub znajomości na poziomie niewystarczającym zapewnia się mu przez okres roku dodatkowe, bezpłatne lekcje z języka polskiego. Dodatkową naukę języka polskiego organizuje organ prowadzący szkołę.

Szczegółowe warunki udzielania dodatkowych, bezpłatnych lekcji z języka polskiego określa także Rozporządzenie Ministra Edukacji Narodowej z 1 kwietnia 2010 roku. Zgodnie $\mathrm{z}$ art. 5 ust. 2 nauka ta prowadzona jest $\mathrm{w}$ wymiarze pozwalającym na opanowanie języka polskiego, w stopniu umożliwiającym udział w obowiązkowych zajęciach edukacyjnych, jednak nie mniejszym niż 2 godziny lekcyjne w tygodniu.

Oprócz dodatkowych, bezpłatnych godzin z języka polskiego dziecko cudzoziemskie w polskiej szkole ma prawo do dodatkowego wsparcia w postaci zajęć wyrównawczych w celu uzupełnienia różnic programowych (art. 94a ust. 4c). Zajęcia organizowane są przez organ prowadzący na wniosek nauczyciela przedmiotu, który stwierdzi braki w materiale i prowadzone w czasie pierwszych 12 miesięcy uczęszczania dziecka do szkoły w wymiarze jednej godziny tygodniowo na przedmiot.

Rozporządzenie z dnia 1 kwietnia 2010 roku wprowadza pewne ograniczenia - wszystkie dodatkowe zajęcia wyrównujące szanse, na które uczęszcza cudzoziemiec - a zatem język polski i zajęcia wyrównawcze - nie mogą łącznie przekroczyć 5 godzin dydaktycznych tygodniowo.

Dotychczasowe rozważania poświęcone były aspektom prawnym regulującym sytuację ucznia cudzoziemskiego w polskiej szkole. W dalszej części tekstu poruszone zostaną zagadnienia związane z rolą szkoły i nauczyciela w edukacji międzykulturowej. Jednak zanim to nastąpi, zasadne jest omówienie głównych jej założeń.

\section{Edukacja międzykulturowa jako wyzwanie edukacyjne}

Podejmując problematykę edukacji międzykulturowej, warto zwrócić uwagę na dwa pojęcia: „edukacja wielokulturowa” i „,edukacja międzykulturowa”, które w literaturze i praktyce edukacyjnej częstokroć stosowane są zamiennie.

Przemysław Grzybowski uważa, że „w przeciwieństwie do edukacji wielokulturowej zmierzającej ku asymilacji mniejszości poprzez jej podporządkowanie grupie dominującej i utrzymaniu statycznego status quo, skutkiem edukacji międzykulturowej ma być integracja i dynamizacja społeczno-kulturowa różnych kręgów społecznych, oparta na wzajemnym zbliżeniu ich członków" (Grzybowski, 2007: 39). 
Bardzo podobnie edukację wielokulturową i edukację międzykulturową pojmuje Tadeusz Lewowicki, którego zdaniem ta pierwsza często nosi piętno podejścia hegemonistycznego i instrumentalnego, a celem jej poczynań edukacyjnych jest asymilacja lub utrzymanie spokoju społeczeństwa, ta druga zaś ma służyć nie „byciu obok”, ale wzajemnemu zbliżeniu - integracji bez jawnego czy ukrytego programu dominacji którejś z grup (Lewowicki, 2001: 25-26).

Zdaniem Jerzego Nikitorowicza „zadania edukacji wielokulturowej wynikają z potrzeby dostosowania szkolnictwa do zjawiska wielokulturowości, a zadania edukacji międzykulturowej polegają na wychowaniu ku wielokulturowości, wyjściu naprzeciw" (Nikitorowicz, 1995: 116). Dodaje, że wielokulturowość jest faktem, zaś międzykulturowość zadaniem i wyzwaniem edukacyjnym (Nikitorowicz, 1999: 25).

Traktując za Nikitorowiczem międzykulturowość jako zadanie i wyzwanie edukacyjne, dalszą część rozważań poświęcę zagadnieniom edukacji międzykulturowej i roli szkoły w tym procesie, gdyż, jak pisze Mirosław Sobecki „jedynie w szkole na odpowiednią skalę można inicjować zmiany w świadomości dotyczące stosunku wobec tego, co odmienne kulturowo. Chodzi jedynie o to, aby potencjał szkoły został wykorzystany" (Sobecki, 1999: 96).

Stanisław Nazaruk uważa, że edukacja międzykulturowa pełni funkcję przygotowania dzieci do spotkania $\mathrm{z}$ rówieśnikami o innej kulturze. Ma za zadanie uwrażliwić młodych ludzi i uświadomić im, że pomimo różnic kulturowych, etnicznych czy religijnych ludzie mogą żyć razem, mogą się ze sobą integrować, mogą współistnieć. W społeczeństwie międzykulturowym najważniejsza jest zasada „bycia razem”, nigdy „bycia obok” (Nazaruk, 2014: 248-249). Edukacja międzykulturowa sprzyjać ma „poznawaniu, rozumieniu i akceptowaniu różnych kultur i tworzących je ludzi” (Lewowicki, Grodzka-Mazur, Szczurek-Boruta, 2000: 17). A ponadto ma przygotować „do współpracy i wzajemnego korzystania z dorobku ludzi różnych ras, narodowości, wyznań, kultur" (Lewowicki, Grodzka-Mazur, Szczurek-Boruta, 2000: 17). Komunikowanie międzykulturowe wiąże się z przekraczaniem granic własnej kultury w celu wzbogacenia wewnętrznego i nabycia umiejętności porównywania w kategoriach nie co lepsze czy gorsze, lecz w kategoriach: inne, ciekawe, motywujące, wartościujące, zastanawiające (Nikitorowicz, 2007: 49).

Wynikające z założeń edukacji międzykulturowej cele dotyczą szczególnie następujących spraw: otwartości wobec świata oraz nowego wymiaru porozumiewania się, nieograniczonego rasą, językiem, religią, tradycją czy pochodzeniem społecznym, a także zaangażowaniem na rzecz pokoju, równości, poszanowania i godności Innych (Suchodolska, 2009: 267). 
Realizacja wyżej wymienionych założeń edukacji międzykulturowej stanowi trudne zadanie dla polskich szkół, a szczególnie dla nauczycieli. W tym miejscu należy postawić sobie pytanie: czy i na ile polskie szkoły są przygotowane na realizację założeń edukacji międzykulturowej? A ponadto: jaką rolę odgrywa nauczyciel $\mathrm{w}$ procesie wychowania ku tolerancji, odrzucania negatywnych stereotypów i uprzedzeń, a także otwartości na drugiego człowieka z poszanowaniem jego pochodzenia? Czy jest on wystarczająco przygotowany do pracy z Innym? Dalsza część tekstu będzie próbą odpowiedzi na postawione pytania.

We wrześniu 2015 roku minister edukacji Joanna Kluzik-Rostkowska zapewniała, że polski system edukacji jest przygotowany na przyjęcie dzieci uchodźczych oraz że konkretne szkoły i konkretni nauczyciele otrzymają wsparcie, gdy będzie wiadomo, że właśnie tam trafią uczniowie uchodźcy (http://www.oswiata.abc.com.pl/ czytaj/-/artykul/men-polski-system-edukacji-przygotowany-na-przyjecie-uchodzcow). Wiceminister Ewa Dudek twierdziła zaś, że nauczyciele pracujący z dziećmi cudzoziemskimi mają możliwość uzyskania wsparcia w formie warsztatów czy dłuższych form szkoleniowych, a także skorzystania z publikacji poświęconych tematyce wielokulturowości w szkole (www.portalsamorzadowy.pl).

Zapewnienia o gotowości przyjęcia uchodźców do polskich szkół skomentowali w liście otwartym do premier Ewy Kopacz przedstawiciele Związku Nauczycielstwa Polskiego, informując, że

przygotowanie szkół nie polega bowiem na zapewnieniu miejsca w klasach, kolorowego papieru i ołówków (...). Jeśli dzieci uchodźców mają poczuć się w polskich szkołach dobrze, a ich rodzice mają mieć poczucie, że są one w naszych placówkach bezpieczne i szczęśliwe, należy już dziś przystąpić do stworzenia koncepcji kształcenia dzieci uchodźców i współpracy z ich rodzicami, należy także przygotować szkolenia dla nauczycieli z placówek, do których dzieci te zostaną skierowane, oraz zaprojektować działania adresowane do społeczności lokalnych, w których znajdują się te placówki. (www.znp.edu.pl)

Brak przygotowania polskich szkół do pracy z cudzoziemcami potwierdzają także liczne badania. Izabela Czerniejewska dowodzi, że nauczyciele nie czują się kompetentni merytorycznie i metodologicznie do pracy w klasie zróżnicowanej narodowościowo. Badani przez nią nauczyciele przyznają, że nie mieli wcześniejszego przygotowania do pracy z cudzoziemcami w trakcie studiów pedagogicznych. Często nie wchodzą w interakcje z uczniami, nie pytają o ich kulturę, bo, jak sami tłumaczą, nie są przygotowani na odpowiedź uczniów pochodzących $z$ innych krajów, która mogłaby wywołać reakcję polskich uczniów (niekoniecznie pozytywną) (Czerniejewska, 2013: 172-173). Zdaniem Edyty Januszewskiej nauczycielom brak wiedzy na temat problemów, z jakimi borykają się dzieci uchodźcy, 
wskazując na zespół stresu pourazowego. Nie zdają sobie także sprawy, jak mogą one wpływać na ich problemy szkolne (edukacyjne i trudności w integracji z rówieśnikami). (Januszewska, 2010: 265-326).

Jak wskazuje Izabela Czerniejewska, nauczycieli cechuje niska kompetencja międzykulturowa, a także brak świadomości wyzwań związanych z pracą z Innym (Czerniejewska, 2008: 65-114). Należy w tym miejscu podkreślić, że w edukacji międzykulturowej szczególne są relacje pomiędzy uczniami i nauczycielami. To ci drudzy odpowiadają za proces integracji, wychowania ku tolerancji i poszanowania Innego i to na nich spoczywa obowiązek kształtowania kompetencji międzykulturowej. Jak zatem należy rozumieć wspomnianą kompetencję? Oraz w jaki sposób ją wykształcić wśród uczniów?

\section{Kształtowanie kompetencji międzykulturowej jako jedno z wyzwań edukacji międzykulturowej}

Kompetencja w ujęciu Marii Czerepaniak-Walczak jest to termin służący do „określenia dyspozycji człowieka, którą osiąga się w ciągu życia przez wyuczenie” (Czerepaniak-Walczak, 1994: 134). Dyspozycje rozumie jako zespół cech psychofizycznych, na który składają się: wiedza, umiejętności, doświadczenia, zdolności, ambicje, motywacja, wartości, postawy oraz style działania jako atrybut człowieka wykorzystywany do realizacji celów i zadan życiowych (Czerepaniak-Walczak, 1994: 134).

Kompetencje międzykulturowe nauczyciela powinny podnieść jakość i zwiększyć skuteczność jego oddziaływań. Należy je rozpatrywać jako proces „stałego wzrastania osobowościowego oraz świadomościowego, które wymaga zaangażowania emocjonalnego oraz silnej motywacji” (Szczurek-Boruta, 2013: 157), a ich nabywanie polega na kulturowym doświadczaniu (Szczurek-Boruta, 2013: 163). Alina Szczurek-Boruta, odwołując się do cyklicznego modelu kulturowego doświadczania Patricka R. Morgana, zaprezentowała przebieg procesu kształtowania kompetencji międzykulturowej uczniów, przywołując przykłady działań nauczycieli w tym zakresie:

1) Knowing About - gromadzenie informacji na temat języka i kultury docelowej, na przykład nauczyciel czyta uczniom teksty o codziennym życiu i zwyczajach, podając przykłady różnic pomiędzy kulturami, opowiada o własnych przeżyciach, a także prezentuje anglojęzyczne filmy;

2) Knowing How - nabywanie umiejętności właściwego zachowania językowego i pozajęzykowego w konkretnej sytuacji, na przykład nauczyciel stwa- 
rza sytuacje, w których uczniowie mogą zmagać się z różnymi trudnościami, wcielając się w role innych osób;

3) Knowing Why - odkrywanie i rozumienie systemu wartości, sposobów postępowania i postrzegania specyficznych dla danej kultury, na przykład nauczyciel rozmawia z uczniami, analizuje i porównuje tradycje i zwyczaje danej kultury, wskazuje różnice i podobieństwa i jak one wpływają na odbiór komunikatu językowego;

4) Knowing Oneself - refleksja nad systemem wartości własnej kultury, który determinuje ludzkie zachowanie, a także zdobywanie wiedzy o własnym „Ja”, na przykład nauczyciel podkreśla na zajęciach, że nie ma złych pomysłów, że każdy człowiek jest ważny, wyjątkowy i niepowtarzalny oraz ma prawo do własnego zdania i wyrażania swoich poglądów (Szczurek-Boruta, 2013: 164).

Konkludując, rozwój kompetencji międzykulturowej nie odbywa się tylko i wyłącznie poprzez bezpośredni kontakt z ludźmi pochodzącymi z odmiennych kręgów kulturowych, ale także w sposób pośredni - dzięki zajęciom dydaktycznym prowadzonym przez nauczycieli, zawierającym treści międzykulturowości.

Aby wykształcić w uczniach kompetencję międzykulturową, szkoły podejmują liczne działania. Na uwagę zasługuje pomysł mentorów stworzony w Społecznym Gimnazjum nr 20 „Raszyńska” w Warszawie, czemu poświęcona zostanie dalsza część rozważań.

\section{Dobre prakłyki edukacji międzykulturowej na przykładzie Społecznego Gimnazjum nr 20 „Raszyńska” w Warszawie'}

Społeczne Gimnazjum nr 20 „Raszyńska” w Warszawie jest jedną z siedmiu szkół² Zespołu Społecznych Szkół Ogólnokształcących „Bednarska” w Warszawie. Swoją działalność rozpoczęło w 1999 roku i od roku 2000 znajduje się przy ul. Raszyńskiej. Od początku istnienia Gimnazjum do sierpnia 2015 roku, funkcję dyrektora pełniła dr Krystyna Starczewska - polonistka, filozof, etyk, pedagog. W 1989 roku poświęciła się tworzeniu „Bednarskiej” - I Społecznego Liceum Ogólnokształcącego w Warszawie przy ul. Bednarskiej oraz Społecznego Gimnazjum nr 20 w Warszawie.

${ }^{1}$ Opis działalności Społecznego Gimnazjum nr 20 w Warszawie powstał w oparciu o wywiad przeprowadzony z dyrektorem Krystyną Starczewską i innymi pracownikami szkoły. Zdjęcia zamieszczone $\mathrm{w}$ tekście zostały wykonane przez autorkę tekstu lub zaczerpnięte $\mathrm{z}$ archiwum szkoły.

${ }^{2}$ W skład Zespołu Szkół Ogólnokształcących „Bednarska” w Warszawie, wymieniając w kolejności ich powstawania, wchodzą: I Społeczne Liceum Ogólnokształcące - 1990 r., Społeczne Gimnazjum nr 20 - 1999 r., Liceum z Maturą Międzynarodową - IBO - 2003 r., Wielokulturowe Liceum Humanistyczne - 2006 r., Gimnazjum na Startowej - 2007 r., Szkoła Podstawowa - 2011, Społeczne Gimnazjum Hispaniola - 2013 r. 
Od roku szkolnego 1998/1999 patronem szkoły jest hinduski maharadża Jam Saheb Digvijay Sinhji. Był on wielkim przyjacielem Polaków. W czasie II wojny światowej uratował ponad tysiąc polskich dzieci, które po strasznych przeżyciach w obozach na Syberii i stracie rodziców uchodziły z terenów Związku Radzieckiego. Maharadża stworzył dla nich w Indiach prawdziwy dom, wychował je, wykształcił, dbając o zachowanie ich tożsamości religijnej i narodowej. Stąd też uznano, że najlepszym sposobem uczczenia pamięci niezwykłego Maharadży będzie uznanie go za patrona polskiej szkoły.

Główną ideą wychowawczą Społecznego Gimnazjum nr 20 w Warszawie jest to, że szkoła

nie jest nastawiona na ostrą rywalizację między uczniami i na osiągnięcie spektakularnych sukcesów. Nie walczymy za wszelką cenę o miejsca w rankingach. Obok uczniów bardzo zdolnych, którzy świetnie zdają egzaminy wstępne, przyjmujemy także dzieci wymagające dodatkowej opieki - chore, niepełnosprawne, borykające się z kłopotami psychologicznymi. Przyjmujemy także dzieci uchodźców i dzieci z domów dziecka, którym gwarantujemy bezpłatną naukę (...) staramy się, aby nasza szkoła była dobrym miejscem nie tylko dla prymusów, ale także dla tych, którzy potrzebują edukacyjnej i wychowawczej pomocy (...). (https://stronarasz.idu.edu.pl)

Pierwsi cudzoziemcy do Zespołu Szkół „Bednarska” zostali przyjęci w 1995 roku. Byli to uczniowie z Ośrodka dla Uchodźców w Dębaku - z Grecji i Czeczenii. Od roku szkolnego 2003/2004 imigranci i uchodźcy zaczęli uczyć się na Raszyńskiej razem z Polakami - do czterech obcokrajowców na klasę, albo w oddzielnych grupach, gdzie intensywnie uczyli się języka polskiego, by móc później dołączyć do standardowej klasy. Do 2007 roku do szkoły uczęszczali uczniowie z Armenii, Wietnamu, Chin, Somalii, Burundi, Kirgistanu, Inguszetii i Bangladeszu. W latach 2008-2013 powitano według kolejności przybycia: Iran, Kubę, Mongolię, Afganistan, Bośnię i Hercegowinę, Turcję, Izrael i Wybrzeże Kości Słoniowej. W roku szkolnym 2013/2014 do szkoły dołączyli uczniowie z trzech nowych krajów: do klas pierwszych doszedł chłopiec z Holandii, dziewczyny z Serbii i Nigerii. Oprócz tego, co roku dojeżdżają nowi Ormianie, Czeczeni, Białorusini. Na obecną chwilę w „Raszyńskiej" uczą się osoby z 17 krajów (ponad 70 dzieci uchodźców i imigrantów).

Zdaniem Kai Malanowskiej - byłej nauczycielki w Społecznym Gimnazjum nr 20 w Warszawie

praca z klasą wielokulturową - czyli taką, w której uczą się dzieci na przykład o różnym pochodzeniu kulturowym i religijnym, zróżnicowanym poziomie wiedzy w stosunku do swojego rocznika czy też różnym poziomie znajomości języka polskiego - wymaga dostosowania zajęć do indywidualnych potrzeb ucznia czy uczennicy, zastosowania innych niż zazwyczaj metod nauczania, jak również cierpliwości w czasie długiego i trudnego procesu 
kształtowania się więzi między nauczycielem czy nauczycielką a dziećmi (...) większość czeczeńskich uczniów i uczennic, z którymi pracowałam, przeżywało traumę wojenną, która odcisnęła na nich trwałe i smutne piętno. Takie dzieci bywają wycofane, nieufne i często agresywne. Chociaż zazwyczaj nauka języka polskiego przychodzi im łatwo, mają trudności z dostosowaniem się do rygorów systemu szkolnego. Wiele z nich popada w konflikty z polskimi rówieśnikami i rówieśniczkami (...). Część z nich nigdy wcześniej nie chodziła do szkoły (...). Wiele z nich nie potrafiło odnaleźć się w warunkach szkoły jako instytucji, wymagającej punktualności, systematycznej pracy i określonej dyscypliny. (Malanowska, 2012: 25-27)

Analizowane praktyki w Gimnazjum nr 20 wprowadzają wiele rozwiązań, dostosowując metody kształcenia, wychowania i integracji do potrzeb uczniów przede wszystkim tych nieznających języka polskiego. Jednym z ciekawych pomysłów, sprawdzających się jako dodatkowa metoda wsparcia, jest przygotowanie pomieszczenia i budynku szkoły na przyjęcie dzieci niemówiących po polsku, na przykład naklejanie karteczek z nazwami na każdym przedmiocie w klasie. Dzięki temu dzieci nieznające języka polskiego mają szansę przyswoić sobie podstawowe określenia (Malanowska, 2012: 29).

Uczniowie cudzoziemscy uczęszczający na „Raszyńską” początkowo trafiają do rocznej klasy multikulturowej, gdzie w grupie około 12 uczniów uczą się języka polskiego oraz polskiej kultury w wymiarze $4-5$ godzin dziennie. Nauka ta połączona jest $\mathrm{z}$ wyjściami do teatru, muzeum, restauracji, organizowane są wyjazdy integracyjne, w których biorą udział także polscy uczniowie. W klasie tej uczy jeden nauczyciel z przygotowaniem do nauki języka polskiego jako obcego. Po roku nauki w tej klasie rada pedagogiczna decyduje, czy uczeń opanował język polski i jest gotowy do nauki w klasie standardowej, czy musi powtarzać kolejny rok w klasie „multi-kulti”. Dla uczniów niemówiących po polsku, którzy skończyli 16 lat, stworzono klasę „multi-kulti extra” - po 2-3 latach intensywnej nauki mogą wybrać liceum lub szkołę zawodową.

Międzykulturowość na „Raszyńskiej” widać już na samym wejściu do budynku. Na korytarzu szkolnym rozwieszone są flagi krajów pochodzenia wszystkich uczniów uczęszczających do szkoły.

Dzieci cudzoziemskie, zwłaszcza te nie mówiące po polsku, na samym początku uczą się słabiej, dlatego też należy stwarzać warunki, aby mogły się wykazać swoją bogatą wiedzą na temat świata albo innymi zdolnościami (plastycznymi, muzycznymi itp.). Przykładem takiego działania może być zrealizowany projekt „Wielość, która nas wzbogaca”, który obejmował zajęcia o kulturze, historii i tradycji krajów pochodzenia dzieci cudzoziemskich uczęszczających do szkoły. W ramach projektu uczniowie przynosili zdjęcia, obrazy i inne rekwizyty, 

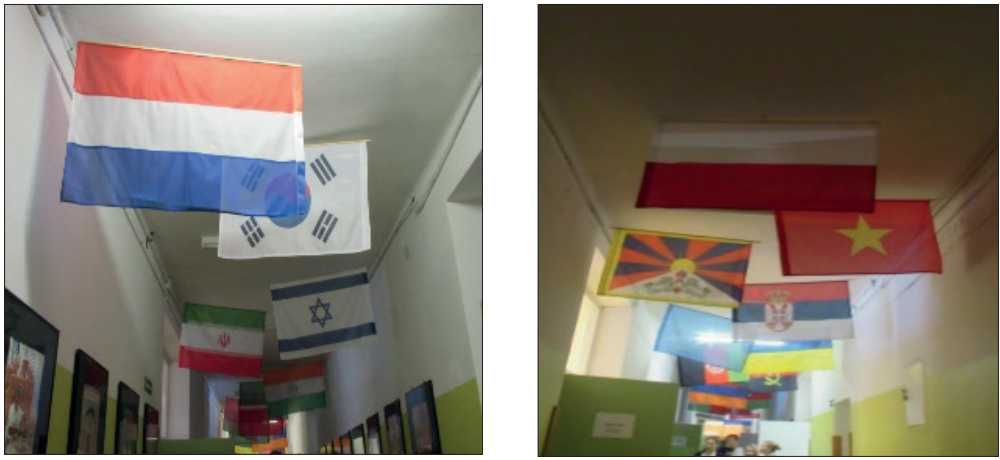

Ryc. 1 i 2. Korytarz szkolny w Społecznym Gimnazjum nr 20 „Raszyńska”

dekorując tym samym szkołę w stylu indyjskim (nawiązanie do patrona szkoły). Warto zaznaczyć, że w realizowanych projektach biorą udział zarówno uchodźcy, jak i uczniowie polscy, a ich celem jest spotkanie się z grupą odmienną kulturowo, poznanie wartości tej kultury i próba akceptacji.
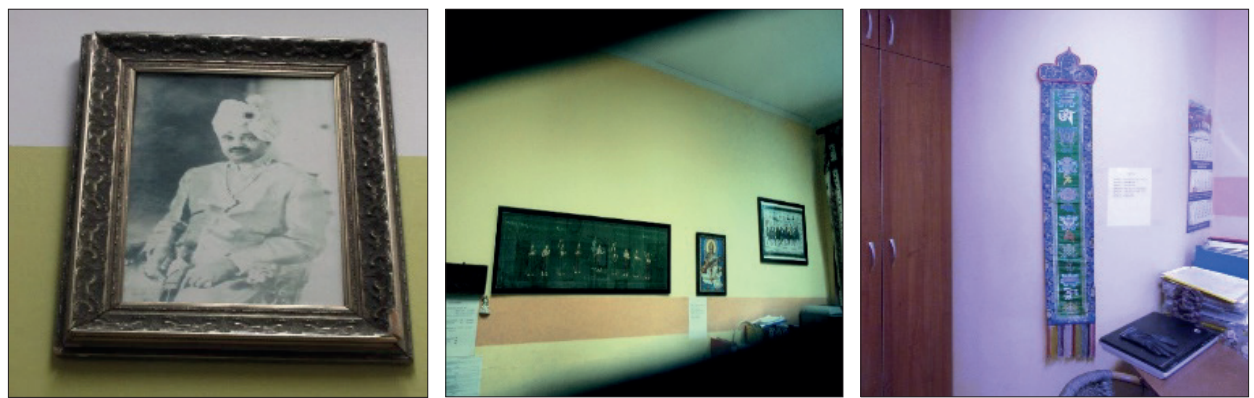

Ryc. 3, 4, 5. Korytarz i sekretariat szkoły

Międzykulturowość widać nie tylko wewnątrz budynku szkoły, ale także wokół niej. Na „Raszyńskiej” nawet mury szkolne ozdobione zostały przez czeczeńskich uczniów. Przestawiają one przywódców, którzy są w ich pamięci, co dało im szansę na stworzenie swojej „małej ojczyzny”.
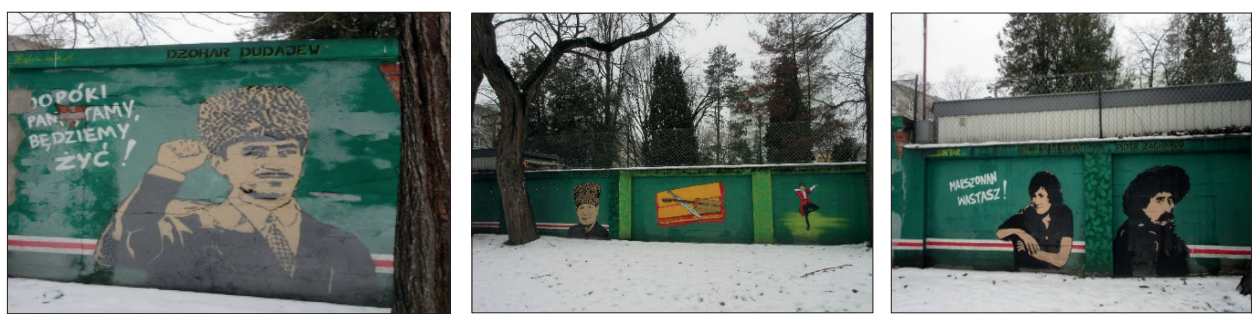

Ryc. 6, 7, 8. Mury szkolne 
Kolejnym ciekawym pomysłem na rzecz integracji uczniów jest działalność Klubu Wielokulturowego, dzięki któremu cudzoziemcy mają okazję poznawać kulturę polską, zwyczaje i obyczaje. Organizowane są różnego rodzaju wyjścia: do teatru, muzeum, restauracji, a także wyjazdy integracyjne. Raz w miesiącu organizowany jest wieczór poświęcony danej kulturze, podczas którego dzieci uczą się tańca, poznają smaki kuchni, kulturę itp. W ramach działalności Klubu Wielokulturowego zapraszani są goście z krajów pochodzenia uczniów.

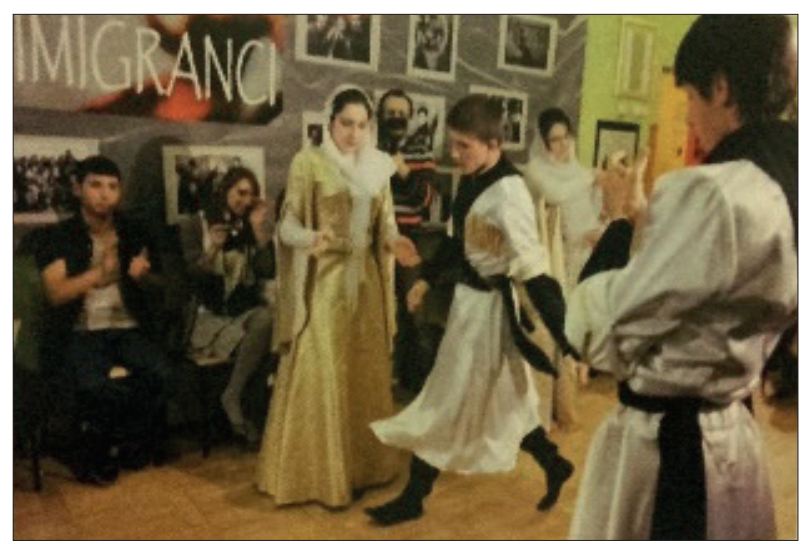

Ryc. 9. Czeczeński taniec ludowy

Źródło: archiwum szkoły

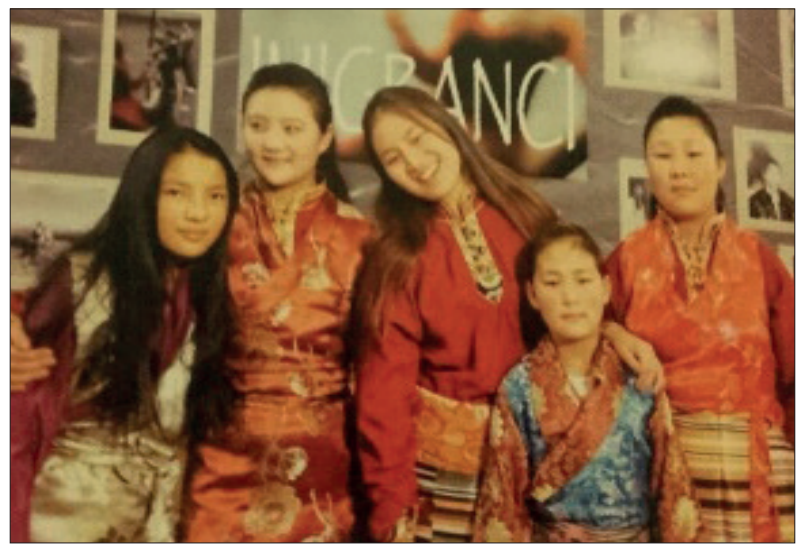

Ryc. 10. Uczennice z Tybetu

Źródło: archiwum szkoły 


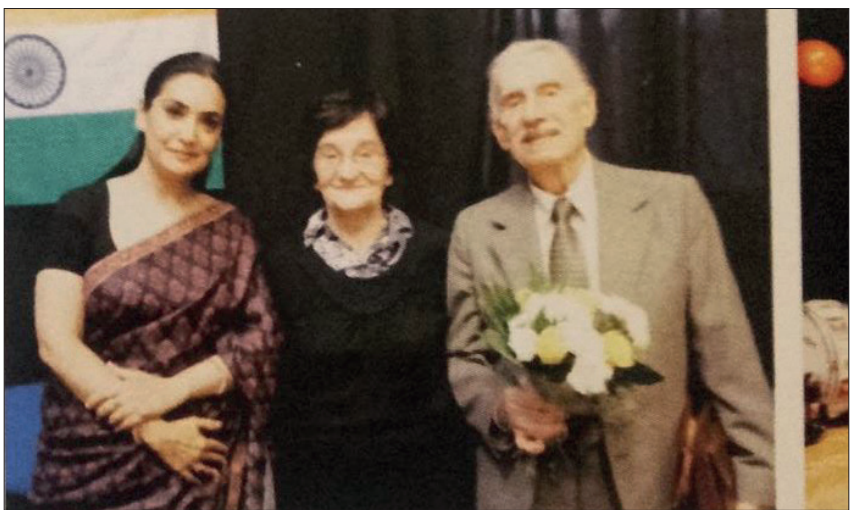

Ryc. 11. Od lewej: Ambasador Indii, dyrektor Krystyna Starczewska, wychowanek patrona szkoły

Źródło: archiwum szkoły

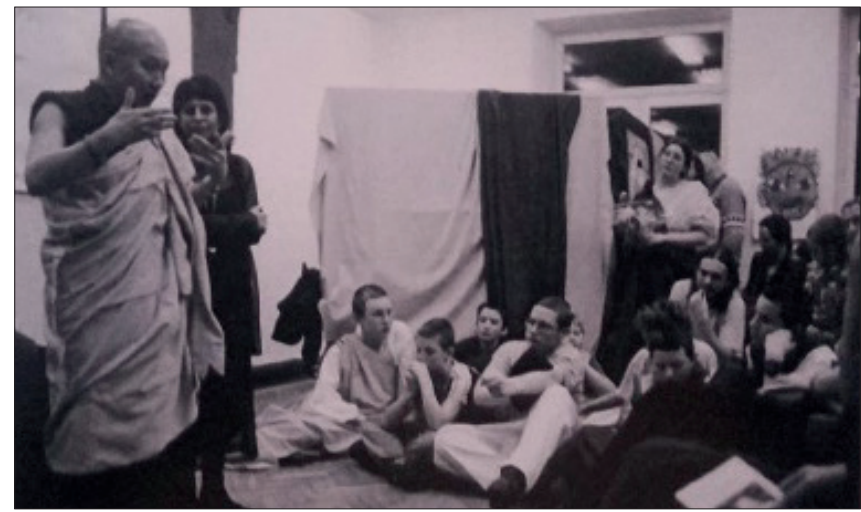

Ryc. 12. Mnich z Tybetu

Źródło: archiwum szkoły

Z inicjatywy szkoły powstała także świetlica dla małych dzieci uchodźców, która prowadzona jest przy pomocy wolontariuszy (uczniów szkoły). Dwa razy w tygodniu autokar przywozi dzieci z Ośrodka dla Uchodźców do szkoły, gdzie organizowane są różnego rodzaju gry i zabawy integracyjne. W kalendarz imprez szkolnych na stałe wpisały się dwa wydarzenia: Choinka i Dzień Dziecka.

Szkoła bardzo chętnie organizuje własne koncerty charytatywne, a uzyskane pieniądze przekazuje na różnorodne cele. W 2011 koncertowali na rzecz budowy studni w Somalii, a dwa lata wcześniej - w roku 2009 na rzecz budowy szkoły w Birmie. Z zebranych funduszy powstał murowany budynek szkolny wyposażony w podstawowe pomoce naukowe. Jako wyraz wdzięczności urodzona tam dziewczynka otrzymała imię Polska. 

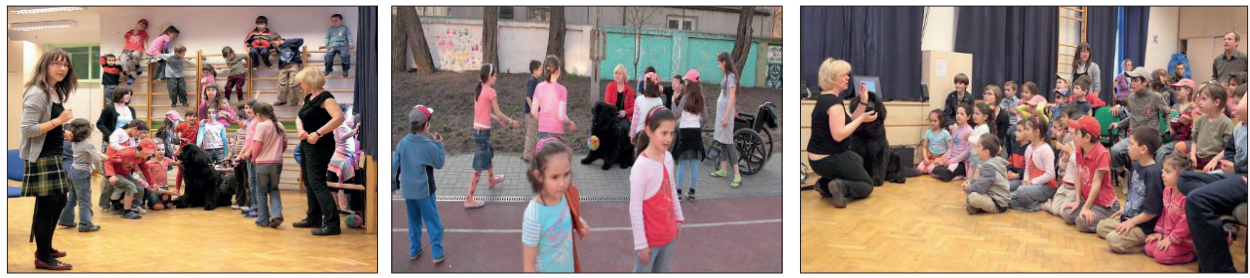

Ryc. 13, 14, 15. Działalność świetlicy

Źródło: archiwum szkoły
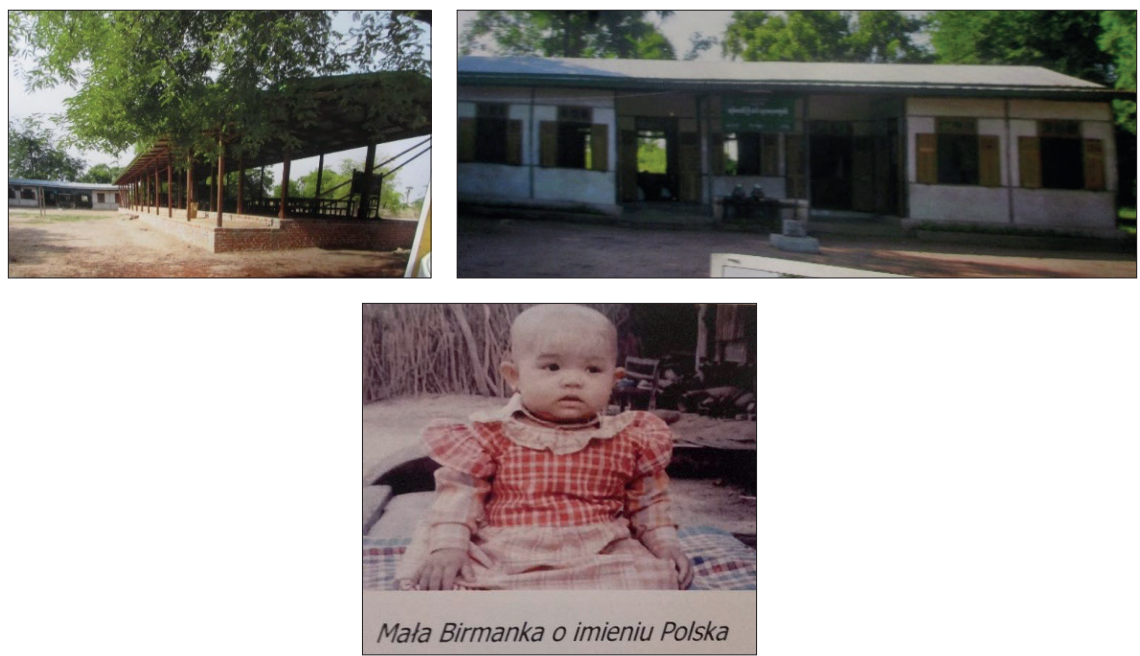

Ryc. 16, 17, 18. Szkoła letnia i zimowa w Birmie Źródło: archiwum szkoły

Reasumując, edukacja międzykulturowa to nie tylko nauka dzieci cudzoziemskich. Z niej także czerpią polscy uczniowie, nauczyciele i rodzice. Jest to wymiana wiedzy, doświadczeń, uczenie się od siebie nawzajem.

\section{Zakończenie}

Rosnąca w ostatnich latach fala migracji spowodowała, że do polskich szkół z roku na rok trafia coraz więcej dzieci obcokrajowców. Polskie placówki edukacyjne na mocy prawa zobowiązane są do przyjęcia dzieci cudzoziemców. Jak pisze Kaja Malanowska, warunkiem niezbędnym w gotowości szkoły na przyjęcie cudzoziemców jest nie tylko przygotowanie samego pomieszczenia klasy, ale także dobranie odpowiednio zajęć, znajomość wiedzy o kulturze, religii i tradycjach kraju dziecka 
cudzoziemskiego, co ułatwia nauczycielowi budowanie pozytywnych relacji z uczniami cudzoziemskimi, a także przygotowanie polskich uczniów na ich przyjęcie (Malanowska, 2012: 33).

Mimo iż w wielu szkołach uczniowie cudzoziemcy od lat stanowią integralną część społeczności szkolnej, wyniki badań wskazują, że dla sporej części nauczycieli kształcenie obcokrajowców $i$ wspieranie ich w procesie integracji jest wyzwaniem. Należy się w tym miejscu zastanowić, czy nie należy zadbać o rozszerzenie programu studiów o przedmioty z zakresu edukacji międzykulturowej, tak by studenci, potencjalni nauczyciele, nabyli kompetencji międzykulturowych i byli gotowi zmierzyć się z wyzwaniami międzykulturowości w szkole. Dodatkowym warunkiem sprzyjającym gotowości pracy w szkole z uczniami różnego pochodzenie jest także promowanie dobrych praktyk przez szkoły i inne placówki, które od lat pracują z dziećmi i rodzinami cudzoziemskimi. W Polsce jest wiele szkól, które mogą pochwalić się dobrymi praktykami, a zaprezentowana „Raszyńska” jest tylko przykładem, który może stać się inspiracją dla innych placówek. Warto w tym miejscu zaznaczyć, że nauczyciele mogą liczyć na wsparcie wielu instytucji, które organizują liczne kursy i szkolenia, na przykład ośrodki doskonalenia nauczycieli, UNHCR, Fundacja na rzecz Różnorodności Społecznej (FRS) i wiele innych. Jednakże należy pamiętać, że sukces edukacji międzykulturowej zależy przede wszystkim od zaangażowania się osób ze środowiska szkolnego (Malanowska, 2012: 29).

\section{Literatura}

Czerepaniak-Walczak M. (1994). Między dostosowaniem a zmianą. Elementy emancypacyjnej teorii edukacji. Szczecin.

Czerniejewska J. (2008). Edukacja wielokulturowa w perspektywie antropologii. Poznań.

Czerniejewska I. (2013). Edukacja wielokulturowa. Działania podejmowane w Polsce. Toruń.

Grzybowski P. (2007). Edukacja europejska - od wielokulturowości ku międzykulturowości. Koncepcje edukacji wielokulturowej i międzykulturowej w kontekście europejskim ze szczególnym uwzględnieniem środowiska frankofońskiego. Kraków.

Januszewska E. (2010). Dziecko czeczeńskie w Polsce. Między traumą wojenna a doświadczeniem uchodźstwa. Torun.

Lewowicki T. (2001). O ideach oraz praktykach edukacji wielokulturowej i międzykulturowej. „Ruch Pedagogiczny" nr 1/2, s. 5-11.

Lewowicki T., Grodzka-Mazur E., Szczurek-Boruta A. (red.). (2000). Edukacja międzykulturowa w Polsce i na świecie. Katowice.

Malanowska K. (2012). Nauka w klasie wielokulturowej - refleksje nauczycielki gimnazjum. [W:] N. Klorek, K. Kubin (red.). Innowacyjne rozwiazania w pracy z dziećmi cudzoziemskimi w systemie edukacji. Warszawa, s. 25-37. 